\title{
NILAI KOMPETENSI TERHADAP KUALITAS PELAYANAN DI KECAMATAN MARITENGNGAE KABUPATEN SIDENRENG RAPPANG
}

\author{
MUHAMMAD RUSDI \\ SEKOLAH TINGGI ILMU SOSIAL DAN ILMU POLITIK (STISIP) \\ MUHAMMADIYAH RAPPANG \\ Addy.ogy@Gmail.Com
}

\begin{abstract}
Abstrak
Kompetensi pegawai arsip memegang peranan penting sebagai pusat penyedia layanan dokumen atau arsip. Dokumen atau arsip digunakan sebagai alat pengawasan yang sangat diperlukan dalam rangka kegiatan perencanaan, penganalisaan, pengembangan, perumusan kebijaksanaan, pengambilan keputusan, pembuatan laporan, pertanggungjawaban, penilaian dan pengendalian setepat-tepatnya. Penelitian ini didasarkan pada masalah pokok, yaitu kualitas pelayanan pegawai arsip yang rendah. Hal ini diduga disebabkan oleh belum dijalankannya aspek-aspek Kompetensi pegawai secara menyeluruh .Tujuan penelitian ini adalah untuk mengetahui sejauh mana kualitas pegawai arsip terhadap kualitas pelayanan di kantor Unit Pelaksana Tugas Dinas Pendidikan 12 Kecamatan Maritengngae, Kabupaten Sidenreng Rappang. Penelitian ini dilaksanakan dengan menggunakan metode penelitian deskriptif kuantitatif. Penelitian ini mempunyai 2 variabel yaitu Kompetensi Petugas Arsip ( $X$ ) dan Kualitas Pelayanan ( $Y$ ). Jumlah populasi dalam penelitian ini adalah 186 guru yang terdiri dari 127 Sekolah dasar dan 59 guru Taman Kanak-kanak. Sampel penelitian terdiri dari 65 guru yang ditentukan berdasarkan purposive teknik sampling. Hasil penelitian ini menunjukkan bahwa nilai kompetensi pegawai arsip berada pada kategori baik yaitu 78\%, kualitas pelayanan juga berada pada pada kategori baik sedangkan pengaruh kompetensi terhadap kualitas pelayanan arsip menunjukkan hasil yang baik. Hasil penelitian ini diharapkan dapat meningkatkan kompetensi dan kualitas pegawai arsip dalam meningkatkan kualitas pelayanan kearsipan. Hasil penelitian ini juga diharapakn dapat menjadi rujukan sekaligus memberi informasi kepada pegawai di kantor UPTD lain atau di instansi lain kompetensi sangat berpengaruh untuk meningterhadakatkan kualitas pelayanan kearsipan.
\end{abstract}

Kata Kunci : Arsip, Kompetensi, Kualitas Layanan, 


\section{A. PENDAHULUAN}

\begin{abstract}
Setiap kantor perlu meningkatkan kompetensi pelayanan pegawai dalam melakukan pengelolaan administrasi pengarsipan dan tulis-menulis untuk mencatat berbagai informasi pada lembaran kertas atau warkat (records). Warkat adalah catatan tertulis atau catatan bergambar mengenai sesuatu hal atau peristiwa yang dibuat orang untuk keperluan membantu ingatan pegawai. Pada dewasa ini warkat yang memuat keterangan tertulis tentu diperlukan pada setiap organisasi untuk mencapai tujuan yang telah ditentukan, misalnya; kwitansi, daftar gaji, pembukuan, gambar bagan organisasi, ijazah, surat izin, dan surat -surat organisasi pada umumnya. Warkat mempunyai kegunaan bagi setiap organisasi, oleh karena itu warkat perlu disimpan secara sistematis sehingga apabila sesuatu warkat akan dipergunakan dapat secara cepat ditemukan kembali. Kumpulan warkat disebut sebagai arsip.
\end{abstract}

Arsip mempunyai peranan yang sangat penting bagi suatu kantor. Menurut Barthos (2014:2) yakni: kearsipan mempunyai peranan sebagai pusat ingatan, sebagai sumber informasi dan sebagai alat pengawasan yang sangat diperlukan dalam rangka kegiatan perencanaan, penganalisaan, pengembangan, perumusan kebijaksanaan, pengambilan keputusan, pembuatan laporan, pertanggungjawaban, penilaian dan pengendalian setepattepatnya. Suatu instansi atau organisasi walaupun di dukung oleh beberapa kumpulan warkat, jika sumber daya manusianya tidak memiliki kemampuan atau tidak mengetahui bidang kearsipan maka pelayanan tidak akan berjalan lancar. Menurut Moeheriono (2014:16) Seorang karyawan dalam menjalankan tugasnya pada suatu organisasi harus memiliki lima dimensi kompetensi yaitu: Task skills, Task management skills, Contingency management skills, Job role environment skills, Transfer skills. Pernyataan tersebut didukung oleh Mulyono dkk (2012:40) mengatakan untuk memajukan organisasi pegawai harus selalu aktif baik melalui usulan, himbauan maupun tindakan dalam keikutsertaan memperbaiki administrasi pengarsipan yang lebih baik. Saat ini sudah waktunya dipertimbangkan persyaratan yang harus dipenuhi seorang pegawai kearsipan.

Penelitian ini penting untuk dilakukan karena maju mundurnya suatu organisasi sangat tergantung pada pengelolaan administrasi pengarsipan. Arsip sebagai sumber data harus dapat disimpan dengan baik agar data atau dokumen dapat menjadi aman. Keamanan data dapat terlaksana apabila pegawai arsip memiliki kompetensi kualitas pelayanan administrasi pengarsipan yang baik. Kualitas pelayanan pegawai arsip dalam menemukan kembali maupun dalam mengelola arsip memang sangat berpengaruh terhadap pengelolaan administrasi arsip itu sendiri. Untuk mengetahui kualitas pelayanan dari perspektif pelanggan maka organisasi tersebut seyogianya pegawai harus selalu "Survive" agar kinerjanya dapat lebih ditingkatkan. Bagaimanakah kompetensi pelayanan pegawai arsip di Kantor Unit Pelaksana Teknis Tujuan Penelitian adalah:

1. Untuk mengetahui kompetensi pegawai arsip di kantor unit pelaksana teknis dinas pendidikan kecamatan Maritengngae kabupaten Sidenreng Rappang.

2. Untuk mengetahui kualitas pelayanan pegawai arsip dikantor unit pelaksana teknis dinas pendidikan kecamatan Maritengngae kabupaten Sidenreng Rappang.

3. Untuk mengetahui pengaruh kompetensi pegawai arsip terhadap kualitas pelayanan pada kantor unit pelaksana teknis dinas pendidikan

kecamatan 
Maritengngae

kabupaten

Sidenreng Rappang.

Tinjauan Pustaka

1. Konsep Kompetensi

Kompetensi dianggap sebagai aspek penting dalam meningkatkan sumber daya manusia. Peningkatan kompetensi dapat dilakukan dalam diri sendiri maupun dalam kelompok. Menurut Mulyasa (2003) Kompetensi adalah pengetahuan, keterampilan dan nilai-nilai a yang mencerminkan pemikiran dan tindakan yang dilakukan oleh pegawai. Sedangkan Medley dan Shannon (1994) mendefinisikan bahwa kompetensi adalah pengetahuan dan keterampilan yang diperlukan untuk melaksanakan melaksanakan tugas yang dibebankan kepadanya. Kompetensi dapat didefinisikan sebagai karakteristik yang mendasari seseorang berkaitan dengan efektifitas kinerja individu dalam pekerjaannya atau karakteristik dasar individu yang memiliki hubungan kausal atau sebagai sebab-akibat dengan kriteria yang dijadikan acuan, efektif atau berkinerja prima atau superior di tempat kerja atau pada situasi tertentu (Acompetency is an underlying characteristic of an individual that is causally related to criterian referenced effective and or superior performance in a job or situation), Spencer dalam Moeheriono (2014:5)

Standar

kompetensi

merupakan kesepakatan tentang kompetensi yang diperlukan untuk suatu bidang pekerjaan oleh seluruh "stakeholder" di bidangnya. Pernyataan lain, yang dimaksud dengan standar kompetensi adalah perumusan tentang kemampuan yang harus dimiliki seseorang untuk melakukan suatu tugas atau pekerjaan yang didasari atas pengetahuan, keterampilan, dan sikap kerja sesuai dengan unjuk kerja yang dipersyaratkan. Standar kompetensi tersebut jika dikuasai oleh seseorang, yang bersangkutan akan mampu: (1) mengerjakan suatu tugas atau pekerjaan; (2) mengelola pekerjaan tersebut agar dapat dilaksanakan; (3) mengetahui apa yang harus dilakukan jika terjadi sesuatu yang berbeda dengan rencana semula; dan (4) menggunakan kemampuan yang dimilikinya untuk memecahkan masalah atau melaksanakan tugas dengan kondisi yang berbeda.

2. Dimensi Kompetensi

Moeheriono (2014:16) ada lima dimensi kompetensi yang harus dimiliki oleh semua individu, terutama untuk seorang karyawan dalam menjalankan tugasnya pada suatu organisasi, yaitu sebagai berikut :

a. Task skills yaitu keterampilan untuk melaksanakan tugas-tugas rutin sesuai dengan standar di tempat kerja.

b. Task management skills yaitu keterampilan untuk mengelola serangkaian tugas yang berbeda yang muncul dalam pekerjaan.

c. Contingency management skill yaitu keterampilan mengambil tindakan yang cepat dan tepat bila timbul suatu masalah dalam pekerjaan.

d. Job role environment skills yaitu keterampilan untuk bekerja sama serta memelihara kenyamanan lingkungan kerja.

e. Transfer skill yaitu keterampilan untuk beradaptasi dengan lingkungan kerja baru.

Michael Zwell dalam Wibowo (2008:102) mengungkapkan bahwa terdapat beberapa faktor yang dapat memengaruhi kecakapan kompetensi seseorang, yaitu sebagai berikut: Keyakinan dan nilai-nilai, Keterampilan, Pengalaman, Karakteristik kepribadian, Motivasi, Isu Emosional, Kemampuan Intelektuan, Budaya Organisasi.

Model kompetensi ini merupakan model yang menekankan kepada kecerdasan emosi pegawai dalam melakukan administrasi arsip. Menurut Goleman (2000) yang mengatakan bahwa model ini mencakup lima bagian utama yaitu kesadaran sendiri, emosi, motivasi, empati, dan keterampilan sosial. Kelima-lima model dapat 
dijelaskan lebih rinci sebagai berikut;

3. Konsep Kualiatas Pelayanan Kualitas merupakan suatu ukuran yang menyatakan seberapa jauh telah dipenuhi berbagai persyaratan, spesifikasi dan harapan. Konsep ini dapat hanya berorientasi kepada masukan, keluaran atau keduanya. Disamping itu kualitas juga berkaitan dengan proses produksi yang akan berpengaruh pada kualitas hasil yang dicapai secara keseluruhan (Sedarmayanti, 2011:227), Sedangkan kualitas menurut ISO 9000 dalam Rambat Lupiyoadi (2013:212) adalah derajat yang dicapai oleh karakteristik yang inheren dalam memenuhi persyaratan. Persyaratan dalam hal ini adalah kebutuhan atau harapan yang dinyatakan, biasanya tersirat atau wajib. Jadi, kualitas sebagaimana yang di interpretasikan ISO 9000 Kualitas merupakan perpaduan antara sifat dan karakteristik yang menentukan sejauhmana keluaran dapat memenuhi persyaratan kebutuhan pelanggan.

beberapa penulis mendefinisikan pelayanan sebagai suatu perbuatan (deed), suatu kinerja (performance) atau suatu usaha (effort) Warella dalam Harbani Pasolong (2014:132). Sedangkan menurut Kotler dalam Laksana (2008:85) pelayanan adalah setiap tindakan atau kegiatan yang dapat ditawarkan oleh satu pihak kepada pihak lain, yang pada dasarnya tidak berwujud atau tidak dikaitkan oleh satu produk fisik. Undang-Undang Nomor 25 tahun 2009 tentang Pelayanan Publik, sebagaimana tertera pada Bab I Ketentuan Umum dalam Pasal 1 bahwa yang dimaksud dengan:

a. Pelayanan publik adalah kegiatan atau rangkaian kegiatan dalam rangka pemenuhan kebutuhan pelayanan sesuai dengan peraturan perundangundangan bagi setiap warga Negara dan penduduk atas barang, jasa, dan/atau pelayanan administratif yang disediakan oleh penyelenggara pelayanan publik.

b. Penyelenggaraan pelayanan publik adalah setiap institusi penyelenggara Negara, korporasi, lembaga independen yang dibentuk berdasarkan UndangUndang untuk kegiatan pelayanan publik, dan badan hukum lain yang dibentuk semata-mata untuk kegiatan pelayanan publik (Mukarom, HZ dan Laksana, MW, 2015:132). 


\section{B. METODOLOGI PENELITIAN}

1. Lokasi dan Waktu Penelitian Lokasi penelitian adalah Kantor Unit Pelaksana Teknis Dinas Pendidikan Kecamatan Maritengngae Kabupaten Sidenreng Rappang yang membawahi dua tingkat sekolah yaitu: 32 Sekolah Dasar Negeri (SDN) dan 26 Taman Kanak-kanak pada Kantor Unit Pelaksana Teknis Dinas Pendidikan Kecamatan Maritengngae Kabupaten Sidenreng Rappang. Penelitian ini memiliki dua variable yaitu variabel pertama kompetensi pegawai arsip sebagai independent variable $(X)$ dan variabel kedua yakni kualitas pelayanan pegawai administrasi pengarsipan sebagai dependent variable. Penelitian ini menggunakan Metode Penelitian Kuantitatif. Data penelitian ini dikumpulkan dengan menggunakan angket. Angket digunakan dalam mengumpulkan data karena mudah untuk diproses dan dianalisis melalui rumus-rumus statistik maupun komputer (Masyuri dan Zainuddin, 2008:13).

\section{Populasi dan Sampel}

Populasi pada penelitian ini adalah seluruh pegawai negeri sipil yang mengajar di sekolah lingkup Unit Pelaksana Teknis Dinas Pendidikan Kecamatan Maritengngae Kabupaten Sidenreng Rappang berjumlah 186 orang.

Sampel penelitian ini diambil dari sebagian populasi yang telah ditetapkan (Jamaluddin Ahmad, 2015:140). Jumlah sampel dalam penelitian ini adalah 65 orang yang diambil dengan menggunakan cara purposive sampling (bertujuan).

Pengumpulan data dilakukan dengan melalui Observasi, Kuisioner Studi Kepustakaan. Penelitian ini menggunakan angket atau kuesioner untuk mengumpulkan data. Angket atau kuesioner dibagikan kepada semua guru yang sudah ditunjuk sebagai sampel penelitian. Guru diambil sebagai sampel karena mereka yang paling merasakan langsung tentang dampak pelayanan di kantor Unit Pelaksana Teknis Dinas Pendidikan Kecamatan Maritengngae. Guru yang ditunjuk sebagai sampel penelitian diberi kesempatan 3 hari untuk menjawab angket dengan harapan mereka mempunyai cukup waktu untuk menjawab secara jujur dan objektif. Setelah 3 hari peneliti mengumpulkan angket tersebut untuk dilakukan proses analisis data penelitian dengan menggunakan software SPSS.

\section{Teknik Analisis Data}

Penelitian ini dilaksanakan dengan menggunakan statistik deskriptif yaitu statistik yang menggambarkan fenomena atau karakteristik data. Karakteristik data yang digambarkan dalam penelitian ini adalah karakteristik distribusinya, yang terdiri dari nilai frekuensi, pengukuran tendensi pusat, dan disperse data. Nilai frekuensi dilihat dari demografi responden (jenis kelamin, pekerjaan, pendidikan), pengukuran tendensi pusat meliputi mean, median, dan mode dan disperse data meliputi range, standard deviation, dan variances (Jogiyanto, 2004).

\section{HASIL PENELITIAN DAN PEMBAHASAN}

1. Indikator Kompetensi

a. Task skiils (keterampilan tugas) yaitu ketrampilan untuk melaksanakan tugas-tugas rutin sesuai dengan standar di tempat kerja. 
Tabel 4.7

Tanggapan responden mengenai pegawai arsip Kantor Unit Pelaksana Teknis Dinas Pendidikan Kecamatan Maritengngae dalam melaksanakan kinerja tugas-tugas sesuai dengan standar

\begin{tabular}{|l|c|c|c|c|}
\hline $\begin{array}{l}\text { Tanggapan } \\
\text { Responden }\end{array}$ & X & F & F.X & $\begin{array}{c}\text { Persentase } \\
(\%)\end{array}$ \\
\hline Sangat Baik & 5 & 17 & 85 & 26,15 \\
\hline Baik & 4 & 34 & 136 & 52,31 \\
\hline Cukup Baik & 3 & 11 & 33 & 16,92 \\
\hline Kurang Baik & 2 & 2 & 4 & 3,08 \\
\hline Tidak Baik & 1 & 1 & 1 & 1,54 \\
\hline \multicolumn{1}{|l}{ Jumlah } & 65 & 259 & $100 \%$ \\
\hline \\
$\begin{array}{l}\text { Rata-rata } \\
\text { Skor } \frac{\sum}{N}=\frac{259}{65}=3,98 \text { Rata - rata persentase } \frac{3,98}{5} \times 100 \%=79,6 \%\end{array}$ \\
\hline
\end{tabular}

Sumber : Hasil Olah Kuisioner, Februari 2017

Berdasarkan data tersebut di atas menunjukkan bahwa tanggapan responden mengenai pegawai arsip Kantor Unit Pelaksana Teknis Dinas Pendidikan Kecamatan Maritengngae dalam melaksanakan tugas-tugas sesuai dengan standar kinerja adalah 17 orang $(26,15 \%)$ responden menjawab sangat baik, 34 orang $(52,31 \%)$ responden menjawab baik, 11 orang $(16,92 \%)$ responden menjawab cukup baik, 2 orang $(3,08 \%)$ responden menjawab kurang baik, 1 orang $(1,54 \%)$ responden menjawab tidak baik, rata-rata persentase yaitu $79,6 \%$ atau dikategori "Baik".

Sesuai dengan hasil wawancara dengan Ibu Hj. Syamsiah, ST.,M.AP. selaku Kepala Kantor Unit Pelaksana Teknis Dinas Pendidikan Kecamatan Maritengngae mengatakan bahwa:

"Alhamdulillah, tugas-tugas terlaksana sesuai dengan standar kinerja yang ditetapkan"(28 Juni 2018).

b. Task management skills (Keterampilan manajemen tugas) yaitu keterampilan untuk mengelola serangkaian tugas yang berbeda yang muncul dalam pekerjaan.

Tabel 4.8

Tanggapan responden mengenai kecekatan pegawai arsip Kantor Unit Pelaksana Teknis Dinas Pendidikan Kecamatan Maritengngae dapat mengelola arsip secara terampil

\begin{tabular}{|l|c|c|c|c|}
\hline $\begin{array}{l}\text { Tanggapan } \\
\text { Responden }\end{array}$ & X & F & F.X & $\begin{array}{c}\text { Persenta } \\
\text { se (\%) }\end{array}$ \\
\hline $\begin{array}{l}\text { Sangat } \\
\text { Baik }\end{array}$ & 5 & 10 & 50 & 15,39 \\
\hline Baik & 4 & 45 & 180 & 69,23 \\
\hline Cukup Baik & 3 & 6 & 18 & 9,23 \\
\hline $\begin{array}{l}\text { Kurang } \\
\text { Baik }\end{array}$ & 2 & 3 & 6 & 4,61 \\
\hline Tidak Baik & 1 & 1 & 1 & 1,54 \\
\hline \multicolumn{1}{|c|}{ Jumlah } & 65 & 255 & $100 \%$ \\
\hline $\begin{array}{l}\text { Rata-rata } \\
\text { Skor } \\
\frac{\sum F . X}{N}=\frac{255}{65}=3,92 \text { Rata - rata persentase } \frac{3,92}{5} \times 100 \%=78,4 \%\end{array}$ \\
\hline
\end{tabular}

Sumber : Hasil Olah Kuisioner, Februari 2017

Berdasarkan data tersebut di atas menunjukkan bahwa tanggapan responden mengenai kecekatan pegawai arsip Kantor Unit Pelaksana Teknis Dinas Pendidikan Kecamatan Maritengngae dapat mengelola arsip secara terampil adalah 10 orang $(15,39 \%)$ responden menjawab sangat baik, 45 orang $(69,23 \%)$ responden menjawab baik, 6 orang $(9,23 \%)$ responden menjawab cukup baik, 3 orang $(4,61 \%)$ responden menjawab kurang baik, 1 orang $(1,54 \%)$ responden menjawab tidak baik, rata-rata persentase $78,4 \%$ atau dikategrikan "Baik".

Sesuai dengan hasil wawancara dengan IBU hj. Syamsiah, ST.,M.AP. selaku Kepala Kantor Unit Pelaksana 
Teknis Dinas Pendidikan Kecamatan Maritengngae mengatakan bahwa:

"Kalau menurut saya setuju, para pegawai terampil dalam mengelola arsip"(28 Juni 2018).

a. Contingency management skills (Keterampilan manajemen kontingensi) yaitu keterampilan mengambil tindakan yang cepat dan tepat bila timbul suatu masalah dalam pekerjaan.

Tabel 4.9

Tanggapan responden mengenai keterampilan pegawai arsip Kantor Unit Pelaksana Teknis Dinas

Pendidikan Kecamatan Maritengngae dapat mengambil arsip yang dibutuhkan secara cepat dan tepat, digambarkan dalam tabel berikut ini :

\begin{tabular}{|l|c|c|c|c|}
\hline $\begin{array}{l}\text { Tanggapan } \\
\text { Responden }\end{array}$ & X & F & F.X & $\begin{array}{c}\text { Per } \\
\text { sen } \\
\text { tas } \\
\text { e } \\
(\%)\end{array}$ \\
\hline Sangat Baik & 5 & 10 & 50 & $\begin{array}{c}15, \\
39\end{array}$ \\
\hline Baik & 4 & 43 & 172 & $\begin{array}{c}66, \\
15\end{array}$ \\
\hline Cukup Baik & 3 & 11 & 33 & $\begin{array}{c}16, \\
92\end{array}$ \\
\hline Kurang Baik & 2 & 0 & 0 & 0 \\
\hline Tidak Baik & 1 & 1 & 1 & $\begin{array}{c}1,5 \\
4\end{array}$ \\
\hline \multicolumn{2}{|c|}{ Jumlah } & 65 & 256 & $\begin{array}{c}10 \\
0 \%\end{array}$ \\
\hline
\end{tabular}

Rata-rata

Skor

$\frac{\sum F X}{N}=\frac{256}{65}=3,94$ Rata - rata persentase

Sumber : Hasil Olah Kuisioner, Februari 2017

Berdasarkan data tersebut di atas menunjukkan bahwa tanggapan responden mengenai keterampilan pegawai arsip Kantor Unit Pelaksana Teknis Dinas Pendidikan Kecamatan Maritengngae dapat mengambil arsip yang dibutuhkan secara cepat dan tepat adalah 10 orang $(15,39 \%)$ responden menjawab sangat baik, 43 orang $(66,15 \%)$ responden menjawab baik, 11 orang
$(16,92 \%)$ responden menjawab cukup baik, tidak ada responden yang menjawab kurang baik, 1 orang (1,54\%) responden menjawab tidak baik, rata-rata persentase 78,8\% dikategorikan "Baik".

Sesuai dengan hasil wawancara dengan $\mathrm{Ibu} \mathrm{Hj}$. Syamsiah, ST.,M.AP. selaku Kepala Kantor Unit Pelaksana Teknis Dinas Pendidikan Kecamatan Maritengngae mengatakan bahwa:

"Kalau mengenai ini sudah tepat, hanya saja terkadang yang membutuhkan arsip harus menunggu dulu" (28 Juni 2018).

b. Job role environment skills (Keterangan lingkungan peran pekerjaan) yaitu keterampilan untuk bekerja sama serta memelihara kenyamanan lingkungan kerja.

Tabel 4.10

Tanggapan responden tentang kemampuan pegawai arsip Kantor Unit Pelaksana Teknis Dinas Pendidikan Kecamatan Maritengngae menata rapi arsip sehingga mudah dalam menemukan kembali

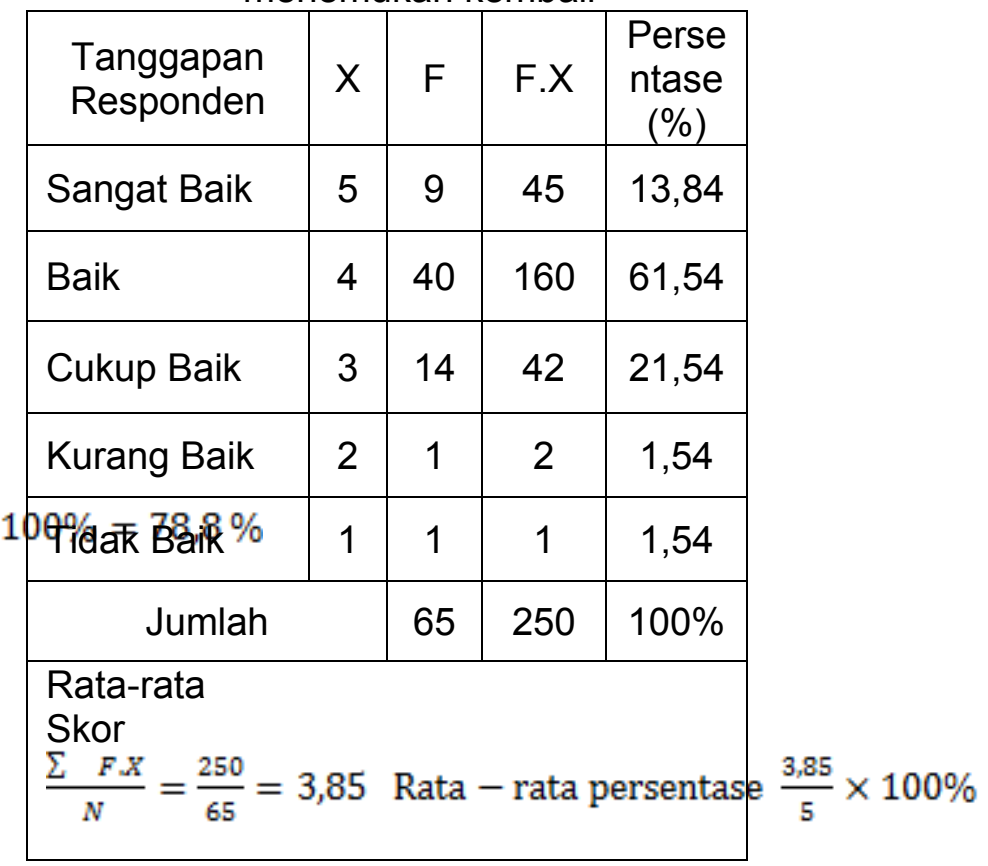

Sumber : Hasil Olah Kuisioner, Februari 2017

Berdasarkan data tersebut di atas menunjukkan bahwa tanggapan responden tentangkemampuan pegawai arsip Kantor Unit Pelaksana Teknis Dinas Pendidikan Kecamatan Maritengngae 
menata rapi arsip sehingga mudah dalam menemukan kembali adalah 9 orang $(13,84 \%)$ responden menjawab sangat baik, 40 orang $(61,54 \%)$ responden menjawab baik, 14 orang $(21,54 \%)$ responden menjawab cukup baik, 1 orang $(1,54 \%)$ responden yang menjawab kurang baik, 1 orang $(1,54 \%)$ responden menjawab tidak baik, rata-rata persentase $77 \%$ atau dikategori "Baik".

Sesuai dengan hasil wawancara dengan $\mathrm{Ibu} \mathrm{Hj}$. Syamsiah, ST.,M.AP. selaku Kepala Kantor Unit Pelaksana Teknis Dinas Pendidikan Kecamatan Maritengngae mengatakan bahwa:

"Untuk saat ini kemampuan menata arsip cukup bagus, hanya saja masih perlu ditingkatkan supaya lebih mudah lagi menemukan arsip yang dibutuhkan pada saat itu juga" (28 juni 2018).

c. Transfer skills (keterampilan transfer) yaitu keterampilan untuk beradaptasi dengan lingkungan kerja baru.

Tabel 4.11

Tanggapan responden tentang kemampuan pegawai arsip Kantor Unit

Pelaksana Teknis Dinas Pendidikan

Kecamatan Maritengngae dapat memperbaiki cara-cara pelaksanaan pengarsipan demi kemajuan

\begin{tabular}{|c|c|c|c|c|}
\hline \multicolumn{5}{|c|}{ organisasi } \\
\hline $\begin{array}{l}\text { Tanggapan } \\
\text { Responden }\end{array}$ & $X$ & $\mathrm{~F}$ & F.X & $\begin{array}{l}\text { Persent } \\
\text { ase (\%) }\end{array}$ \\
\hline Sangat Baik & 5 & 9 & 45 & 13,84 \\
\hline Baik & 4 & 36 & 144 & 55,39 \\
\hline Cukup Baik & 3 & 17 & 51 & 26,15 \\
\hline $\begin{array}{l}\text { Kurang } \\
\text { Baik }\end{array}$ & 2 & 2 & 4 & 3,08 \\
\hline Tidak Baik & 1 & 1 & 1 & 1,54 \\
\hline Jumlah & & 65 & 245 & $100 \%$ \\
\hline$\frac{\sum P B}{N}=\frac{245}{65}=3,77$ & & $\begin{array}{l}\text { a-rat } \\
\text { kor }\end{array}$ & ase $\frac{3,77}{5}$ & $00 \%=75,4 \%$ \\
\hline
\end{tabular}

Berdasarkan data tersebut di atas menunjukkan bahwa tanggapan responden tentangkemampuan pegawai arsip Kantor Unit Pelaksana Teknis Dinas Pendidikan Kecamatan Maritengngae dapat memperbaiki cara-cara pelaksanaan pengarsipan demi kemajuan organisasi adalah 9 orang (13,84\%) responden menjawab sangat baik, 36 orang $(55,39 \%)$ responden menjawab baik, 17 orang $(26,15 \%)$ responden menjawab cukup baik, 2 orang $(3,08 \%)$ responden yang menjawab kurang baik, 1 orang $(1,54 \%)$ responden menjawab tidak baik, rata-rata persentase $75,4 \%$ atau dikategori "Baik".

Sesuai dengan hasil wawancara dengan Ibu $\mathrm{Hj}$. Syamsiah, ST.,M.AP. selaku Kepala Kantor Unit Pelaksana Teknis Dinas Pendidikan Kecamatan Maritengngae mengatakan bahwa:

Berdasarkan tabel dapat dijelaskan bahwa indikator kompetensi di Kantor Unit Pelaksana Teknis Dinas Pendidikan Kecamatan Maritengngae yaitu $77,84 \%$ atau kategori "Baik" yang berdasarkan berbagai pertanyaan sesuai dengan indikator di atas.

Kemudian sesuai dari teori Bab II menurut Moeheriono mengatakan ada lima dimensi kompetensi yang harus dimiliki oleh semua individu, terutama untuk seorang karyawan dalam menjalankan tugasnya pada suatu organisasi. Dari rata-rata persentase yang dihasilkan maka kompetensi pegawai arsip terlaksana dengan baik.

\section{Indikator Kualitas Pelayanan}

Berdasarkan hasil olahan data penelitian dapat dijelaskan bahwa indikator kualitas pelayanan di Kantor Unit Pelaksana Teknis Dinas Pendidikan Kecamatan Maritengngae yaitu $78,92 \%$ atau dikategorikan "Baik" yang berdasarkan berbagai pertanyaan sesuai dengan indikator di atas.

Adapun total keseluruhan nilai dari variabel $X$ (kompetensi pegawai arsip) adalah sebesar 1265. Untuk mengetahui jumlah persentasenya, maka dapat dihitung dengan menggunakan rumus sebagai berikut: 


$$
\begin{gathered}
\text { Hasil Ideal }=\frac{\text { TotalFrekuensijawaban }}{\text { Bobot tertinggi } \mathrm{x} J \text { umlah Pertanyaan } \mathrm{Jumlah} \text { Responden }} \times 100 \% \\
=\frac{1265}{5 \times 5 \times 65}=\frac{1265}{1625}=0.78 \times 100 \%=78 \% \\
\text { Jadi, nilai Kompetensi Pegawai } \\
\text { Arsip adalah sebesar } 78 \% \text { dari } \\
100 \% \text { hasil yang diharapkan. } \\
\text { Adapun total keseluruhan nilai } \\
\text { dari variabel Y (Kualitas Pelayanan) } \\
\text { adalah sebesar 1283. Untuk } \\
\text { mengetahui jumlah persentasenya, } \\
\text { maka dapat dihitung dengan } \\
\text { menggunakan rumus sebagai berikut: }
\end{gathered}
$$

$$
\begin{gathered}
\text { Hasil Ideal }=\frac{\text { TotalFrekuensiawaban }}{\text { Bobot tertinggi } \times \text { Jumlah Pertanyaan } \times \text { Jumlah Responden }} \times 100 \% \\
=\frac{1283}{5 \times 5 \times 65}=\frac{1283}{1625}=0.79 \times 100 \%=79 \% \\
\text { Jadi, niali Kualitas Pelayanan }
\end{gathered}
$$
yaitu sebesar $79 \%$ dari $100 \%$ hasil yang diharapkan.

\section{Kesimpulan}

Setelah melakukan penelitian selama kurang lebih dua bulan maka penulis menarik kesimpulan untuk menjawab pertanyaan rumusan masalah penelitian. Terdapat tiga kesimpulan yang dapat ditarik dari penelitian ini adalah sebagai berikut:

1. Kompetensi pegawai arsip di Kantor Unit Pelaksana Teknis Dinas Pendidikan Kecamatan Maritengngae berjalan dengan kategori baik $78 \%$

2. Kualitas pelayanan di Kantor Unit Pelaksana Teknis Dinas Pendidikan Kecamatan Maritengngae berjalan dengan kategori baik $79 \%$

\section{E. Referensi}

Ahmad, Jamaluddin. 2015. Metode Penelitian Administrasi Publik, Teori dan Aplikasinya. Gava Media. Yogyakarta.

Barthos, Basir. 2014. Manajemen Kearsipan. Bumi Aksara. Jakarta.

Laksana, F. 2008. Manajemen Pemasaran Pendekatan Praktis. Graha Ilmu. Yogyakarta.
Lupiyoadi, Rambat. 2013. Manajemen

Pemasaran Jasa, Berbasis Kompetensi. Salemba Empat. Jakarta.

Masyhuri dan Zainuddin. 2008. Metodologi Penelitian: Pendekatan Prektis dan Aplikatif. Refika Aditama. Bandung.

Wibowo. 2010. Budaya Organisasi. Rajagrafindo Persada. Jakarta.

\section{Dokumen:}

Undang-undang Nomor 43 Tahun 2009 tentang Kearsipan

Undang-undang Nomor 25 Tahun 2009 tentang Pelayanan Publik

\section{Jurnal/Kutipan}

Sundari, 2016. Implementasi UndangUndangNomor 6 tahun 2014 Tentang Desa Terhadap Efektifitas Pengelolaan Badan Usaha Milik Desa di Desa Lagading Kecamatan Pitu Riase Kabupaten Sidenreng Rappang. STISIP M Rappang 